\title{
PENERAPAN MODEL PEMBELAJARAN KOOPERATIF TIPE TRUE OR FALSE UNTUK MENINGKATKAN HASIL BELAJAR PKn SISWA KELAS VII. 1 SMP NEGERI 21 KOTA PEKANBARU
}

\author{
Suriati \\ SMP Negeri 21 Pekanbaru \\ e-mail: suriati62@yahoo.com
}

\begin{abstract}
Activities This devotion is a downstream activity of this Research to find appropriate action in improving student learning outcomes on the subject of Civics in Class VII. 1 in SMP Negeri 21 Kota Pekanbaru with Cooperative Learning Model Type True or False, which is held for 1 month. The subject of this research is the students of class VII. 1 in SMP Negeri 21 Kota Pekanbaru. With a total of 43 students. The form of research is classroom action research. The instrument of this research consists of written test and data collection instrument in the form of observation sheet of teacher activity and student activity. Based on the results of the analysis and discussion can be concluded that the Cooperative Learning Model Type True or False can improve student learning outcomes on the subject of Civics in Class VII. 1 in SMP Negeri 21 Kota Pekanbaru. This success is due to the application of the Cooperative Learning Model Type True or False approach to open and direct interaction among fellow students, giving students time to think and respond as well as helping each other so that more students have the opportunity to express emotional experiences which are fun. With these conditions then the level of student acceptance will increase and in turn can improve learning outcomes.
\end{abstract}

Keywords: Learning Outcomes of Civic Subject, Cooperative Learning Model Type True or False

\begin{abstract}
Abstrak
Kegiatan Pengabdian ini merupakan hilirisasi kegiatan Penelitian ini untuk menemukan tindakan yang tepat dalam meningkatkan hasil belajar siswa pada Mata Pelajaran PKn di Kelas VII. 1 di SMP Negeri 21 Kota Pekanbaru dengan Model Pembelajaran Kooperatif Tipe True or False, yang dilaksanakan selama 1 bulan. Subjek penelitian ini adalah siswa kelas VII. 1 di SMP Negeri 21 Kota Pekanbaru. Dengan jumlah siswa sebanyak 43 orang. Bentuk penelitian adalah penelitian tindakan kelas. Instrumen penelitian ini terdiri dari tes tertulis dan instrumen pengumpulan data berupa lembar observasi aktivitas guru dan aktivitas siswa. Berdasarkan hasil analisis dan pembahasan dapat disimpulkan bahwa dengan Model Pembelajaran Kooperatif Tipe True or False dapat meningkatkan hasil belajar siswa pada Mata Pelajaran PKn di Kelas VII. 1 di SMP Negeri 21 Kota Pekanbaru. Keberhasilan ini disebabkan dengan penerapan pendekatan Model Pembelajaran Kooperatif Tipe True or False menimbulkan interaksi yang bersifat terbuka dan langsung di antara sesama siswa, memberikan kepada para siswa waktu untuk berfikir dan merespons serta saling bantu satu sama lain sehingga siswa lebih banyak memiliki kesempatan untuk mengekspresikan pengalaman emosi yang menyenangkan. Dengan kondisi tersebut maka tingkat penerimaan siswa akan meningkat dan pada gilirannya dapat meningkatkan hasil belajarnya.
\end{abstract}

Kata kunci : Hasil Belajar Mata Pelajaran PKn, Model Pembelajaran Kooperatif Tipe True or False 


\section{PENDAHULUAN}

Pendidikan ditujukan untuk meningkatkan kualitas sumber daya manusia, sebagaimana dirumuskan dalam Tujuan Pendidikan Nasional dalam UU Sisdiknas Nomor 20 Tahun 2003, pasal 3 bahwa "Pendidikan Nasional berfungsi mengembangkan kemampuan dan membentuk watak serta peradaban bangsa yang bermartabat dalam rangka mencerdaskan kehidupan bangsa, bertujuan untuk berkembangnya potensi peserta didik agar menjadi manusia yang beriman dan bertakwa kepada Tuhan Yang Maha Esa, berakhlak mulia, sehat, berilmu, cakap, kreatif, mandiri dan menjadi warga Negara yang demokratis serta bertanggung jawab". Depdiknas (2006:2) dinyatakan bahwa mata pelajaran pendidikan kewarganegaran (PKn) merupakan mata pelajaran yang memfokuskan pada pembentukan diri yang beragam dari segi agama, sosiokultural, bahasa, usia dan suku bangsa untuk menjadi warga negara Indonesia yang cerdas, terampil dan berkarakter yang setia kepada bangsa dan negara Indonesia dengan merefleksikan dirinya dalam kebiasaan berfikir dan bertindak sesuai dengan amanat Pancasila dan UUD 1945.

Untuk mewujudkan tujuan tersebut guru mempunyai fungsi yang sangat penting dan sangat menentukan dalam pembelajaran. Seorang guru yang profesional idealnya memiliki kompetensi pendidikan, yaitu kompetensi pedagogik, profesional, kepribadian, dan sosial. Terutama dalam proses pembelajaran guru dituntut pula menguasai berbagai strategi pembelajaran agar suasana pembelajaran di kelas lebih bergairah dan menyenangkan.

Memperhatikan tujuan Pendidikan Nasional dan pendidikan mata pelajaran PKn, sebaiknya penyelenggara pembelajaran PKn mampu mempersiapkan, membina, dan membentuk kemampuan peserta didik yang menguasai pengetahuan, sikap, nilai dan kecakapan dasar yang diperlukan bagi kehidupan di masyarakat. Untuk menunjang tercapainya tujuan tersebut harus didukung oleh iklim pembelajaran yang kondusif. Iklim pembelajaran yang dikembangkan oleh guru mempunyai pengaruh yang sangat besar terhadap keberhasilan dan kegairahan siswa. Kualitas dan keberhasilan pembelajaran sangat dipengaruhi oleh kemampuan dan ketepatan guru dalam memilih dan menggunakan model pembelajaran.

Berdasarkan pengalaman penulis selaku guru Pendidikan Kewarganegaraan (PKn) di SMP Negeri 21 Kota Pekanbaru, menunjukkan bahwa hasil belajar siswa kelas VII. 1 pada pelajaran PKn masih tergolong rendah. Dari 43 siswa 20 siswa $46.51 \%$ tidak mencapai Kriteria Ketuntasan Minimal (KKM) yang ditetapkan sekolah yakni 65, sedangkan 53.49\% lagi masih berada di bawah nilai KKM. Pada saat pembelajaran berlangsung hanya sebagian kecil siswa (2 3 orang) yang memiliki keinginan bertanya atau mengajukan pendapat. Siswa cenderung bersikap pasif saat pembelajaran di kelas dan sering terlambat dalam mengerjakan tugas yang diberikan guru.

Faktor yang mempengaruhi hasil belajar dapat dibagi menjadi dua faktor yaitu faktor internal dan eksternal. Faktor internal yaitu yang berasal dari dalam diri siswa. Faktor eksternal yaitu faktor yang berasal dari luar diri siswa. Salah satu faktor eksternal yang mempengaruhi hasil belajar siswa adalah cara mengajar/ metode guru dalam menyampaikan materi pelajaran kepada siswa. Berdasarkan kenyataan menunjukkan bahwa cara mengajar guru di kelas cenderung hanya menggunakan cara-cara klasik seperti ceramah ataupun tanya jawab, sehingga siswa cenderung menjadi pasif dan kurang semangat belajarnya. Hal ini dapat menyebabkan penurunan prestasi belajar siswa.

Salah satu usaha yang dapat dilakukan adalah menerapkan metode pembelajaran yang bertujuan mengaktifkan siswa yaitu supaya siswa mau bertanya tentang materi yang sedang dipelajari terlebih dahulu kepada teman sekelompoknya, bersemangat untuk mengerjakan latihan serta mempunyai rasa tanggung jawab dengan tugas dan kelompoknya. Maka perlu digunakan pembelajaran kooperatif. Saat ini metode pembelajaran kooperatif semakin berkembang. Salah satu tipe dalam pembelajaran kooperatif yang yang dapat digunakan adalah tipe True or False (Benar atau Salah). Zaini (2007:24) Pembelajaran kooperatif tipe True or False dapat membuat siswa terlibat secara langsung dengan materi. Selain itu pembelajaran kooperatif dengan tipe True or False akan membuat siswa lebih teliti dalam mempelajari materi.

Berdasarkan uraian di atas penulis tertarik untuk melakukan penelitian menerapkan pembelajaran kooperatif dengan tipe True or False (benar atau salah) dengan harapan dapat meningkatkan hasil belajar PKn siswa kelas IIIA dengan judul "Penerapan Model Pembelajaran 
Kooperatif Tipe True or False untuk Meningkatkan Hasil Belajar PKn Siswa Kelas VII. 1 SMP Negeri 21 Kota Pekanbaru".

\section{METODE}

Penelitian tindakan kelas ini dilaksanakan di Kelas VII. 1 SMP Negeri 21 Kota Pekanbaru Tahun Pelajaran 2016/2017 dengan jumlah siswa sebanyak 43 orang. Penelitian ini dilakukan dalam dua siklus pada bulan November 2016.

Subjek yang diteliti adalah siswa kelas VII. 1 SMP Negeri 21 Kota Pekanbaru Tahun Pelajaran 2016/2017.

Rencana Tindakan

1. Perencanaan

Perencanaan merupakan persiapan yang dilakukan sebelum pelaksanaan tindakan. Adapun yang akan dipersiapkan yaitu:

a. Menyusun RPP berdasarkan langkah-langkah penerapan model pembelajaran koopertif tipe True or False.

b. Meminta kesediaan teman sejawat untuk menjadi observer dalam pelaksanaan pembelajaran.

c. Menyiapkan format pengamatan atau lembar observasi terhadap aktivitas yang dilakukan guru dan aktivitas yang dilakukan siswa dan kisi-kisi soal berkaitan dengan materi yang akan diajarkan.

2. Pelaksanaan Tindakan

Dalam pelaksanaan tindakan kelas yang menggunakan penerapan model pembelajaran koopertif tipe True or False melalui tahapan-tahapan sebagai berikut:

a. Pendahuluan atau kegiatan awal

1) Melakukan tanya jawab tentang pengetahuan yang dimiliki siswa berkaitan dengan materi yang akan disampaikan

2) Melakukan apersepsi dengan mengaitkan pelajaran yang lalu dengan pelajaran yang akan dipelajari.

3) Memotivasi siswa yaitu dengan memberikan pujian kepada siswa yang bisa menjawab pertanyaan yang diajukan guru.

b. Kegiatan inti

1) Menyusun sebuah daftar pernyataan yang terkait dengan jumlah materi pelajaran anda, setengahnya benar dan setengahnya salah. Tiap pertanyaan ditulis dalam satu kertas indeks yang terpisah. Pastikan jumlah kartunya sesuai dengan jumlah siswa yang hadir. (Jika jumlah siswa yang hadir ganjil maka pilihlah satu kartu untuk anda sendiri),

2) Membagikan satu kartu untuk satu siswa. Bahwa misi mereka adalah menentukan kartu mana yang benar dan kartu mana yang salah. (Jelaskan pada mereka, mereka bebas menggunakan cara apa saja yang mereka inginkan untuk menyelesaikan tugas ini).

3) Memerintahkan agar setiap kartu dibaca dan mintakan pendapat siswa tentang benar atau salahkah pernyataan tersebut. Beri kesempatan munculnya pendapat minoritas.,

4) Memberikan umpan balik untuk masing-masing kartu, dan catat cara-cara siswa dalam bekerjasama dalam menyelesaikan tugas ini.,

5) Menunjukkan bahwa dalam pelajaran ini diperlukan ketrampilan tim yang positif karena hal ini menunjukan kegiatan belajar yang sifatnya aktif

c. Kegiatan akhir

1) Guru mengajukan beberapa pertanyaan kepada siswa yang menyangkut pelajaran yang sudah dipelajari

2) Guru memberikan tugas tes tentang pengetahuan baru yang dimiliki siswa.

3. Observasi

3) Guru melakukan rekapitulasi terhadap pencapaian hasil belajar siswa.

Pengamatan atau observasi yang dilakukan dalam penelitian ini dilakukan oleh guru kelas $\mathrm{V}$ yang telah bersedia menjadi observer dalam penelitian ini dengan menggunakan format pengamatan yang telah disediakan. Aspek-aspek yang diamati antara lain: 
a. Aktivitas guru dalam menggunakan model Cooperative learning tipe true or false yang dilakukan dengan menggunakan lembar observasi aktivitas guru

b. Aktivitas siswa selama proses perbaikan pembelajaran dengan mengunakan model Cooperative learning tipe true or false yang dilakukan dengan menggunakan lembar observasi aktivitas siswa

\section{Refleksi}

Setelah perbaikan pembelajaran dilaksanakan guru dan observer melakukan diskusi dan menganalisa hasil dari proses pembelajaran yang dilaksanakan, sehingga diketahui keberhasilan dan kelemahan pembelajaran yang telah dilaksanakan.

Hasil dari analisa data tersebut dijadikan sebagai landasan untuk siklus berikutnya, sehingga antara siklus I dan siklus berikutnya ada kesinambungan dan diharapkan kelemahan pada siklus yang pertama dapat dijadikan sebagai dasar perbaikan pada siklus yang berikutnya.

Adapun data dalam penelitian ini adalah data tentang:

1. Data tentang penggunaan Cooperative learning tipe Think-Pair-Share, yaitu data tentang aktivitas siswa dan aktivitas guru dalam pembelajaran yang diperoleh melalui lembar observasi.

2. Data tentang hasil belajar siswa dalam pembelajaran yang diperoleh melalui tes hasil belajar yang dilaksanakan pada akhir siklus.

\section{HASIL DAN PEMBAHASAN}

\subsection{Hasil}

\subsubsection{Siklus Pertama}

Keberhasilan dalam penerapan pembelajaran kooperatif true or false ini terkait erat dengan aktivitas guru. Dalam penggunaan pembelajaran kooperatif true or false secara umum guru sudah melakukan dengan "cukup sempurna". Hal ini sesuai hasil pengamatan dimana aktivitas guru memperoleh skor 16. untuk lebih jelasnya dapat dilihat pada tabel 4.1

Tabel 1

Aktivitas Guru pada Siklus I

\begin{tabular}{||c|l|ccc|c||}
\hline \hline No & \multicolumn{1}{|c|}{ Pelaksanaan Aktivitas } & \multicolumn{3}{|c||}{ Jumlah } & Skor \\
\hline 1 & Sangat sempurna & 0 & $\mathrm{x}$ & 5 & 0 \\
\hline 2 & Sempurna & 2 & $\mathrm{x}$ & 4 & 8 \\
\hline 3 & Kurang sempurna & 2 & $\mathrm{x}$ & 3 & 6 \\
\hline 4 & Tidak sempurna & 1 & $\mathrm{x}$ & 2 & 2 \\
\hline 5 & Tidak dilaksanakan & 0 & $\mathrm{x}$ & 1 & 0 \\
\hline Jumlah & \multicolumn{5}{|c|}{ Cukup sempurna } \\
\hline \multicolumn{1}{|c|}{} \\
\hline
\end{tabular}

Sumber : Data olahan penelitian, 2016

Aktivitas guru pada siklus I ini berada pada kategori cukup sempurna dengan skor 16 yang berada pada interval 13 - 16. Adapun aktivitas guru yang memperoleh skor sempurna terdapat pada aktivitas kedua (2) Membagikan satu kartu untuk satu siswa dan aktivitas ketiga (3) Bahwa misi mereka adalah menentukan kartu mana yang benar dan kartu mana yang salah. Memerintahkan agar setiap kartu dibaca dan mintakan pendapat siswa tentang benar atau salahkah pernyataan tersebut. Aktivitas guru yang memproleh skor kurang sempurna terdapat pada aktivitas pertama (1) Menyusun sebuah daftar pernyataan yang terkait dengan jumlah materi pelajaran anda, setengahnya benar dan setengahnya salah dan aktivitas kelima (5) Menunjukkan bahwa dalam pelajaran ini diperlukan ketrampilan tim yang positif karena hal ini menunjukan kegiatan belajar yang sifatnya aktif. Aktivitas guru yang memproleh skor tidak sempurna terdapat pada aktivitas keempat (4) Memberikan umpan balik untuk masing-masing kartu, dan catat cara-cara siswa dalam bekerjasama dalam menyelesaikan tugas ini 
Hasil pengamatan aktivitas guru tersebut apabila dianalisis lebih jauh dan diskusikan dengan observer ditemukan beberapa kelemahan seperti berikut ini:

1) Dalam penyajian pembelajaran kooperatif true or false, guru masih kurang bisa memberikan umpan balik untuk masing-masing kartu dan kurang melibatkan siswa secara merata (terfokus pada kelompok tertentu saja).

2) Dalam penyusunan sebuah daftar pernyataan yang terkait dengan jumlah materi pelajaran terlihat kurang sempurna.

3) Ketrampilan tim yang positif belum terbentuk karena hal ini menunjukan kegiatan belajar yang sifatnya pasif.

4) Dalam membangkitkan motivasi siswa dalam belajar, peneliti menyadari belum optimal. Peneliti sering lupa memberikan penghargaan atas keberhasilan siswa dalam belajar atau penghargaan atas hasil kerjanya. Di samping itu, motivasi dan dorongan khusunya kepada siswa yang dianggap lemah untuk mengungkapkan ide-idenya masih kurang.

Berdasarkan pengamatan observer, secara umum pada saat pembelajaran berlangsung sebagian siswa terlihat kurang aktif mengemukakan pendapat sesuai dengan idenya sendiri. Pada saat peneliti meminta siswa lain mengomentari pendapat yang dikemukakan ada hanya sebahagian kecil siswa yang mengungkapkan pendapatnya. Aktivitas siswa ini antara lain didukung oleh hasil observasi "aktivitas siswa" yang diukur dari 5 komponen, aktivitas siswa tergolong rendah dengan skor 86 (Terlampir).

Tabel 2.

Aktivitas Siswa Siklus I

\begin{tabular}{||c|l|c|c||}
\hline No & \multicolumn{1}{|c|}{ Aktivitas siswa } & Skor & \% \\
\hline 1 & $\begin{array}{l}\text { Memperhatikan penjelasan guru terkait dengan materi pembelajaran } \\
\text { yang sedang dipelajari. }\end{array}$ & 19 & 44.2 \\
\hline 2 & Menerima satu kartu yang diberikan oleh guru. & 26 & 60.5 \\
\hline 3 & Membacakan pendapat tentang benar atau salahkah pernyataan tersebut. & 27 & 62.8 \\
\hline 4 & Siswa bekerjasama dalam menyelesaikan tugas & 18 & 41.9 \\
\hline 5 & Menunjukan kegiatan belajar yang sifatnya aktif & 17 & 39.5 \\
\hline Jumlah & $\mathbf{1 0 7}$ \\
\hline Rata-rata & \multicolumn{2}{|c|}{$\mathbf{4 9 . 8}$} \\
\hline Klasifikasi & \multicolumn{2}{c|}{ Rendah } \\
\hline
\end{tabular}

Sumber : Data olahan penelitian, 2016

Dari tabel 4.2 diketahui bahwa jumlah skor aktivitas siswa pada siklus I adalah 107 dengan rata-rata persentase sebesar $49.8 \%$. Walaupun sebagian besar siswa telah menunjukkan minatnya untuk belajar namun masih terdapat siswa yang kurang perhatian dalam belajarnya. Khususnya pada aspek pertama (1) Memperhatikan penjelasan guru terkait dengan materi pembelajaran yang sedang dipelajari hanya 19 orang dari 43 siswa atau sebesar $44.2 \%$ siswa yang tergolong aktif, aspek keempat (4) Siswa bekerjasama dalam menyelesaikan tugas hanya 18 orang dari 43 siswa atau sebesar $41.9 \%$ siswa yang tergolong aktif, dan aspek kelima (5) Menunjukan kegiatan belajar yang sifatnya aktif hanya 17 orang dari 43 siswa atau sebesar $39.5 \%$ siswa yang tergolong aktif. Berkaitan dengan hasil pengamatan ini lebih jauh dapat dijelaskan aktivitas siswa kurang perhatian dan bekerjasama sehingga memperlihatkan kegiatan belajar yang pasif. Hal ini disebabkan karena siswa belum terbiasa dengan pembelajaran yang diterapkan oleh peneliti yaitu penggunaan pembelajaran kooperatif true or false.

Berdasarkan data hasil tes formatif yang dilakukan pada siklus I ini diperoleh rata-rata hasil belajar siswa pada pelajaran PKn sebesar 68.8 (terlampir). Bila kita lihat hasil tersebut secara garis besar bahwa ketuntasan secara klasikal dikatakan tidak tuntas $(<75)$. Secara detail distribusi hasil belajar pada siklus I dapat dilihat pada tabel berikut ini:

Tabel 3.

Distribusi Hasil Belajar pada Siklus I 


\begin{tabular}{||c|c|c|c|c|c||} 
Sangat tinggi & $>85$ & 0 & 0.0 & 0.0 & 100.0 \\
\hline Tinggi & $71-85$ & 23 & 53.5 & 53.5 & 100.0 \\
\hline Sedang & $56-70$ & 13 & 30.2 & 83.7 & 46.5 \\
\hline Rendah & $41-55$ & 7 & 16.3 & 100.0 & 16.3 \\
\hline Jumlah & & $\mathbf{4 3}$ & $\mathbf{1 0 0}$ & & \\
\hline
\end{tabular}

Sumber : Data olahan penelitian, 2016

Dari tabel di atas dapat dilihat bahwa belum terdapat siswa yang mencapai klasifikasi sangat tinggi, sedangkan pada klasifikasi tinggi terdapat 23 orang siswa atau $53.5 \%$, pada klasifikasi sedang terdapat 13 orang siswa atau $30.2 \%$, pada klasifikasi rendah masih terdapat 7 orang siswa atau $16.3 \%$

Dari tabel di atas menunjukkan bahwa secara rata-rata mata pelajaran PKn ini belum mencapai ketuntasan kelas (rata-rata 68.8).

\subsubsection{Siklus Kedua}

Seperti halnya pada siklus pertama, pengamatan didasarkan pada dua hal yaitu; hasil pengamatan langsung yang dilakukan oleh guru dan teman sejawat untuk mengetahui aktivitas guru dalam penggunaan pembelajaran kooperatif true or false dan aktivitas siswa selama pembelajaran, dan untuk hasil belajar siswa tetap dengan menggunakan tes hasil belajar. Mengenai aktivitas guru pada siklus II, dapat dilihat pada tabel berikut ini.

Tabel 4.

Aktivitas Guru pada Siklus II

\begin{tabular}{||c|l|cccc|c||}
\hline \hline No & \multicolumn{1}{|c|}{ Pelaksanaan Aktivitas } & \multicolumn{3}{|c||}{ Jumlah } & Skor \\
\hline 1 & Sangat sempurna & 2 & x & 5 & 10 \\
\hline 2 & Sempurna & 3 & x & 4 & 12 \\
\hline 3 & Kurang sempurna & 0 & x & 3 & 0 \\
\hline 4 & Tidak sempurna & 0 & x & 2 & 0 \\
\hline 5 & Tidak dilaksanakan & 0 & x & 1 & 0 \\
\hline Jumlah & \multicolumn{4}{|c|}{ 22 } \\
\hline Klasifikasi & \multicolumn{5}{|c|}{ Sangat Sempurna } \\
\hline
\end{tabular}

Sumber : Data olahan penelitian, 2016

Adapun mengenai aktivitas guru dalam menggunakan pembelajaran kooperatif true or false, jika pada siklus I guru sudah melakukan dengan "cukup sempurna". Hal ini sesuai hasil pengamatan dimana aktivitas guru memperoleh skor 16. Hasil pengamatan aktivitas guru pada siklus II menunjukkan adanya peningkatan dengan skor 22 dengan kriteria sangat sempurna.

Tabel 5.

Aktivitas Siswa Siklus II

\begin{tabular}{||c|l|c|c||}
\hline \hline No & \multicolumn{1}{|c|}{ Aktivitas siswa } & \multicolumn{1}{|c||}{ Skor } & \% \\
\hline 1 & $\begin{array}{l}\text { Memperhatikan penjelasan guru terkait dengan materi pembelajaran } \\
\text { yang sedang dipelajari. }\end{array}$ & 35 & 81.4 \\
\hline 2 & $\begin{array}{l}\text { Menerima satu kartu yang diberikan oleh guru. } \\
3\end{array}$ & 33 & 76.7 \\
\hline 4 & Membacakan pendapat tentang benar atau salahkah pernyataan tersebut. & 36 & 83.7 \\
\hline 5 & 32 & 74.4 \\
\hline
\end{tabular}




\begin{tabular}{||l|c||}
\hline Jumlah & 169 \\
\hline Rata-rata & 78.6 \\
\hline Klasifikasi & $\begin{array}{c}\text { Sangat } \\
\text { tinggi }\end{array}$ \\
\hline
\end{tabular}

Sumber : Data olahan penelitian, 2016

Berdasarkan pengamatan observer berkaitan dengan aktivitas siswa pada siklus II melalui hasil observasi "aktivitas siswa" yang diukur dari 5 komponen (terlampir), aktivitas siswa memperoleh skor 169 dengan klasifikasi sangat tinggi. Berdasarkan data tersebut di atas, diketahui bahwa adanya peningkatan aktivitas siswa dari skor 107 pada siklus I menjadi 169 pada siklus II dipengaruhi oleh aktivitas guru yang lebih dulu meningkat pada semua indikator yang seiring meningkatnya aktivitas siswa pada setiap indikator.

Berdasarkan data hasil tes formatif yang dilakukan pada siklus I diperoleh rata-rata hasil belajar siswa pada pelajaran PKn sebesar $68.8 \%$. Sedangkan pada siklus II, rata-rata hasil belajar siswa pada pelajaran PKn sebesar 78.6\%. Secara lebih jelas dapat dilihat pada tabel berikut ini:

Tabel 6.

Distribusi Hasil Belajar Siswa pada Siklus II

\begin{tabular}{|c|c|c|c|c|c||}
\hline \hline Klasifikasi & Standar & Frekwensi & \% & $\begin{array}{c}\text { \% } \\
\text { Kumulatif }\end{array}$ & $\begin{array}{c}\text { \% } \\
\text { Kumulatif }\end{array}$ \\
\hline Sangat tinggi & $>85$ & 10 & 23.3 & 23.3 & 100.0 \\
\hline Tinggi & $71-85$ & 30 & 69.8 & 93.0 & 76.7 \\
\hline Sedang & $56-70$ & 3 & 7.0 & 100.0 & 7.0 \\
\hline Rendah & $41-55$ & 0 & 0.0 & 100.0 & 0.0 \\
\hline Jumlah & & $\mathbf{4 3}$ & $\mathbf{1 0 0}$ & & \\
\hline
\end{tabular}

Sumber : Data olahan penelitian, 2016

Dari tabel di atas dapat dilihat telah terdapat siswa yang mencapai klasifikasi sangat tinggi yaitu 10 orang siswa atau $23.3 \%$, sedangkan pada klasifikasi tinggi terdapat 30 orang siswa atau $69.8 \%$, pada klasifikasi sedang terdapat 3 orang siswa atau $7 \%$, tidak ada lagi siswa pada klasifikasi rendah.

Dari tabel hasil belajar siklus II menunjukkan bahwa secara rata-rata mata pelajaran PKn ini telah mencapai ketuntasan kelas dengan rata-rata $79.8 \%$. Jika dibandingkan dengan hasil belajar pada siklus I menunjukkan adanya peningkatan yang besar.

Hal ini yang perlu diungkapkan dari pengamatan pada siklus kedua adalah bahwa kelemahan-kelemahan yang terjadi pada siklus I telah berhasil diatasi pada siklus II ini. Untuk melihat data pemantauan pelaksanaan aktivitas siswa dalam pembelajaran pada siklus kedua ini dapat dilihat pada lampiran.

\subsection{Pembahasan}

Dari hasil penelitian pada siklus I menunjukkan bahwa hasil belajar belum mencapai indikator yang ditetapkan. Hal ini disebabkan pengelolaan pembelajaran pada siklus I yang belum optimal seperti dijelaskan dalam siklus I. Hal ini mengindikasikan bahwa proses pembelajaran yang dibawakan peneliti masih perlu perencanaan yang lebih baik dengan memperhatikan kelemahan kekuatan yang telah teridentifikasi pada siklus I sebagai dasar perbaikan pada siklus II.

Perbandingan antara hasil belajar pada Siklus I dan Siklus II secara jelas dapat dilihat pada Tabel berikut ini: 
Tabel 7.

Rekapitulasi Hasil Belajar pada Siklus I dan Siklus II

\begin{tabular}{|c|c|c|c|c|c|c|c|c|c|}
\hline \multicolumn{3}{|c|}{ Pembelajaran } & \multicolumn{5}{|c|}{ Siklus I Siklus II } \\
\hline Klasifikasi & Standar & Frek & $\%$ & $\%$ Kum & $\%$ Kum & Frek & $\%$ & $\%$ Kum & $\%$ Kum \\
\hline Sangat tinggi & 785 & 0 & 0.0 & 0.0 & 100.0 & 10 & 23.3 & 23.3 & 100.0 \\
\hline Tinggi & $71-85$ & 23 & 53.5 & 53.5 & 100.0 & 30 & 69.8 & 93.0 & 76.7 \\
\hline Sedang & $56-70$ & 13 & 30.2 & 83.7 & 46.5 & 3 & 7.0 & 100.0 & 7.0 \\
\hline Rendah & $41-55$ & 7 & 16.3 & 100.0 & 16.3 & 0 & 0.0 & 100.0 & 0.0 \\
\hline Jumlah & & 43 & 100 & & 43 & 100 & & \\
\hline
\end{tabular}

Sumber : Data olahan penelitian, 2009

Berdasarkan tabel di atas diketahui bahwa terjadinya peningkatan hasil belajar dari siklus I ke siklus II. peningkatan siswa yang mencapai klasifikasi sangat tinggi sebesar 10 orang siswa atau $23.3 \%$, pada klasifikasi tinggi sebesar 30 orang siswa atau $69.8 \%$. Jumlah siswa yang mendapatkan nilai di atas 70 (Ketuntasan minimal) pada siklus I berjumlah 23 orang atau sebesar 53.5\%, sedangkan pada siklus II naik menjadi 40 orang atau $93.02 \%$. Keadaan ini menunjukkan bahwa perbaikan pembelajaran pada mata pelajaran PKn dengan menggunakan pembelajaran kooperatif true or false dapat dikatakan berhasil, meskipun ketuntasan individu belum tercapai sepenuhnya. Perbandingan antara hasil belajar pada siklus I dan II juga dapat dilihat pada histogram berikut ini.

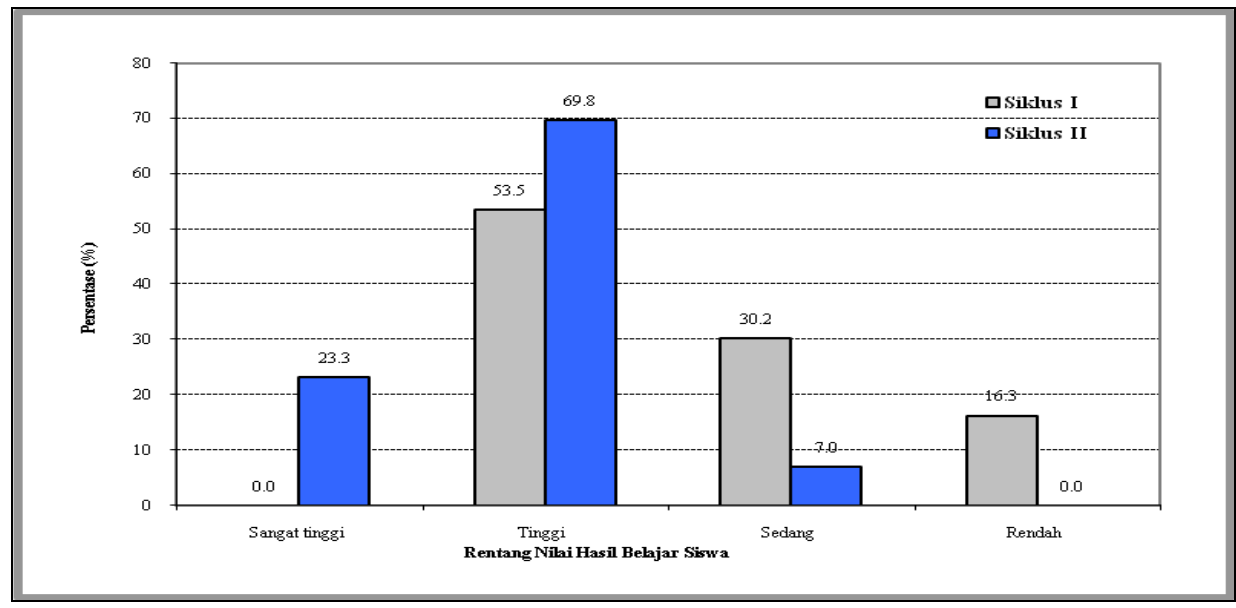

Gambar 1. Histogram Hasil Belajar Siswa pada Siklus I dan II

Kelemahan-kelemahan penggunaan pembelajaran kooperatif true or false pada siklus I tersebut setelah diperbaiki pada siklus II dan mencapai tingkat sangat sempurna ternyata dapat meningkatkan hasil belajar siswa. Melalui perbaikan penggunaan pembelajaran kooperatif true or false pada siklus II tersebut, hasil belajar siswa yang mendapatkan nilai di atas 70 (Ketuntasan minimal) pada siklus II sebanyak 40 orang dari 43 orang siswa atau sebesar $93.02 \%$.

Meningkatnya hasil belajar pada siklus II dibandingkan pada siklus I menunjukkan bahwa perbaikan pembelajaran yang dibawakan dapat memecahkan permasalahan yang dihadapi. Artinya, perencanaan pembelajaran yang dibuat sesuai untuk mengatasi permasalahan rendahnya hasil belajar siswa yang terjadi di dalam kelas selama ini. Selanjutnya, adanya peningkatan hasil belajar siswa pada mata pelajaran PKn dari sebelumnya kesiklus I dan kesiklus II menunjukkan bahwa penggunaan pembelajaran kooperatif true or false dapat meningkatkan hasil belajar siswa kelas VII. 1 pada mata pelajaran pendidikan kewarganegaraan di SMP Negeri 21 Kota Pekanbaru. 
Keadaan di atas senada dengan pendapat Zaini, dkk (2007:24) mengemukakan bahwa true or false ini merupakan aktifitas kolaboratif yang dapat mengajak siswa untuk terlibat kedalam materi belajar dengan segera. tipe ini menumbuhkan kerjasama tim, berbagi pegetahuan dan belajar secara langsung

Lie (2007:3) mengemukakan bahwa belajar adalah suatu kegiatan yang dilakukan siswa bukan sesuatu yang dilakukan terhadap siswa. Siswa tidak menerima pengetahuan dari guru dan kurikulum yang bersifat pasif. Teori Skemata menjelaskan bahwa siswa mengaktifkan struktur kongitif mereka dan membangun struktur-struktur baru untuk mengakomodasi masukan-masukan pengetahuan yang baru (lie, 2007:3) jadi, siswa sebagai peserta yang aktif.

Berdasarkan kedua penjelasan tersebut di atas dan dari berbagai penelitian yang telah mereka lakukan itu, maka tidak perlu kita ragukan lagi tentang pentingnya metode pengajaran dalam meningkatkan hasil belajar siswa

\section{KESIMPULAN}

Berdasarkan hasil analisis dan pembahasan dapat disimpulkan bahwa penggunaan pembelajaran kooperatif true or false dapat meningkatkan hasil belajar siswa kelas VII. 1 pada mata pelajaran pendidikan kewarganegaraan di VII. 1 SMP Negeri 21 Kota Pekanbaru. Hal ini dapat dilihat dari rata-rata hasil belajar siswa pada siklus I adalah $68.8 \% \%$ dengan kategori tidak tuntas dan mengalami peningkatan pada siklus II menjadi 79.8 dengan kategori tuntas. Jumlah siswa yang mendapatkan nilai di atas 70 (Ketuntasan minimal) pada siklus I berjumlah 23 orang atau $53.5 \%$, sedangkan pada siklus II naik menjadi 40 orang atau 93.02\%. Berdasarkan indikator kinerja yaitu penelitian ini dikatakan berhasil apabila ketuntasan belajar mencapai $75 \%$ dari seluruh siswa. (I.G.A.K. Wardani, 2004:4.21).

Keberhasilan ini disebabkan penggunaan pembelajaran kooperatif true or false yang dapat menumbuhkan kerjasama tim, berbagi dan belajar pengetahuan secara langsung. Pembelajaran yang belum pernah diterapkan peniliti ini juga menitik beratkan pada ketrampilan tim yang positif dan menunjukan kegiatan belajar yang sifatnya aktif. Peningkatan pemahaman siswa terhadap materi pelajaran seiring dengan meningkatnya hasil belajar siswa.

\section{SARAN}

Berdasarkan pembahasan sebelumnya, peneliti mengajukan beberapa saran, yaitu:

1. Agar pelaksanaan penggunaan pembelajaran kooperatif true or false lebih sering diterapkan karena dapat memberikan hasil yang optimal.

2. Pelaksanaan pembelajaran kooperatif true or false akan lebih efektif apabila guru telah memahami benar kelebihan dan memanfaatkan dari kekurangan metode ini.

3. Perlunya modifikasi dan perbaikan dari metode sebelumnya untuk menciptakan metode pembelajaran yang lebih sempurna.

1) Perlunya penggunaan metode belajar yang bervariatif demi pencapaian hasil belajar yang optimal.

\section{DAFTAR PUSTAKA}

[1] Arikunto, Suharsimi, Suhardjono, dan Supardi, 2006, Penelitian Tindakan Kelas, Jakarta, Bumi Aksara,

[2] Depdiknas, 2006, Kurikulum Tingkat Satuan Pendidikan, Jakarta, Pusat Kurikulum, Balitbang Depdiknas,.

[3] Dimyati dan Mudjiono, 2002, Belajar dan Pembelajaran, Jakarta, Rineka Cipta,

[4] Gimin, Dkk. 2005. Pedoman Penulisan Karya Ilmiah Mahasiswa. FKIP. UNRI.

[5] _ 2006. Instrumen dan Pelaporan Hasil Penelitian Tindakan Kelas. Pekanbaru. Makalah Pelatihan

[6] Kunandar. 2007. Guru Profesional Implementasi Kurikulum Tingkat Satuan Pendidikan (KTSP) Dan Persiapan Menghadapi Sertifikasi Guru. Jakarta PT. Raja Grafindo Persada,. 
[7] Lie, Anita. (2007). Coopetative Learning. Jakarta. Grasindo.

[8] Sanjaya, Wina. 2007. Strategi Pembelajaran Berorientasi Standar Proses Pendidikan. Jakarta. Kencana,

[9] Sardiman.2004. Interaksi dan Motivasi Belajar Mengajar. Jakarta. Rajawali pers

[10] Silberman, L. Malvin, 2006, Active Learning. Bandung, Nusamedia.

[11] Slavin, Robert E, 2008, Cooperative learning Teori, Riset dan Praktis. Bandung Nusa Media.

[12] Syah, Muhibbin. 2007. Psikologi Belajar. Bandung. Remaja rosda karya.

[13] Tu,u. 2004. Peran Disiplin Pada Perilaku dan Prestasi Siswa. Jakarta. Grasindo

[14] Zaini, Hisyam dkk. 2007. Strategi Pembelajaran Aktif. Yogyakarta. CTSD. 